\title{
The Dual Perspectives in James Thomson's The City of Dreadful Night
}

\author{
Kawther Mahdi Al-Zwelef ${ }^{1}$ \\ ${ }^{1}$ Faculty of Arts, Zarqa University, Jordan \\ Correspondence: Dr. Kawther Mahdi Al-Zwelef, Associate Professor, Faculty of Arts, Zarqa University, Jordan. \\ E-mail: kawther48@yahoo.com
}

Received: March 7, 2013 Accepted: April 3, 2013 Online Published: April 26, 2013

doi:10.5539/ells.v3n2p16 URL: http://dx.doi.org/10.5539/ells.v3n2p16

\begin{abstract}
This paper will deal primarily with Thomson's interesting dual perspectives employed in portraying the Victorian life's crises depicted in his masterpiece The City of Dreadful Night. Each of these perspectives will be analyzed according to its face value first, and then according to what might a gifted writer, like Thomson, had in mind and yearned symbolically to declare by adopting such a method in writing the poem.

The City of Dreadful Night has earned justly the Victorian poet James Thomson (B. V.) a distinct place in English literature. It is a unique poem in its insightful earnestness, force of thought and its pointed verses; that turned it into a truly remarkable poem, deserving to be considered a predecessor to T. S. Eliot's The Wasteland. The City of Dreadful Night is an extremely intriguing poem; not just for the dark vision of humanity and its future the poem presents, but precisely for the multiplicity of levels with which its poet handles such an enigmatic topic.
\end{abstract}

Keywords: the dual entities in The City of Dreadful Night, $19^{\text {th }}$ century wasteland, the sick city, the crises of, estrangement, enlightened skepticism, pessimism, the futility of human existence in an alien world belief

\section{Introduction}

Some of James Thomson's Victorian contemporaries deliberately denied the existence of certain social, religious and intellectual dilemmas, or at least turned a blind eye to them. Thomson's poetry, on the other hand, ran contrary to the current fashion of the Victorians in this aspect. He felt an obligation to verbalize his intellectual inspirations bluntly; exposing, thus, not only these evils, but defying the widespread insincerely optimistic, superficial and sluggish tone preferred by the early Victorian writers in treating such fundamental issues. ${ }^{(1)}$

Thomson's reputation rests mainly on his pessimistic poems like "The Room," "Insomnia," "To Our Ladies of Death," and certainly The City of Dreadful Night. By investigating the dark sectors of the City of Dreadful Night, Thomson reveals humanity's worthless existence, the dull repetitiveness of life, and the failure of all known systems of belief in providing humanity with relieving answers to its entanglements.

Upon exploring the world of The City of Dreadful Night, we will recognize the wide scope of Thomson's genius, his extremely imaginative power, his vibrant descriptions and his comprehensive human sympathies. However, the most incredible feature of the poem that this paper will spotlight is the manifold levels of interpretations the poem suggests and allows. Such traits would certainly entail James Thomson (B.V.) the notable place he deserves on the English Poets' map of honour, or as Sylvanus Urban, in the Gentleman's Magazine puts it: "at any rate he has won admission into the temple."(2)

\section{James Thomson's Life and Achievements}

The Scottish Victorian poet James Thomson (1834-1882) was the younger of two English poets who carried that name. Thomson was brought up in a religious environment that made him retain the chief tenets of Christian faith throughout his early life. His father became paralyzed when Thomson was six years old, while his mother died when he was only eight. Such events left their imprints on the little boy's life and soul.

In 1842, Thomson was admitted to the Royal Caledonian Asylum. In 1850 he left it to be admitted as a monitor at the Royal Military Asylum, to become later not only one of its most remarkable scholars, but a distinguished literary figure as well. It was during his military service that Thomson became a close friend to Charles Bradlaugh; a friendship which will prove vital to Thomson's life and career. In 1853, Thomson left Ballincollig to Chelsea; which was probably the brightest period in his whole life, during which he gained knowledge, friends, and even the love of the beautiful young Matilda Weller. However, Matilda's premature death was believed to 
trigger Thomson's later depression. His mood changed, he became more philosophical, his mind began to brood over the darker aspects of life, and doubts crept into his old religious beliefs.

Thomson began writing poetry when his interest shifted from mathematics to languages and literature. However, he had the unfortunate habit of destroying his poetry when he does not feel satisfied with it. Subsequently, he burnt most of his early poetry and letters written during that period ${ }^{(3)}$; which might be interpreted, symbolically, as an act of burning his unaccredited literary identity.

The letters Thomson exchanged with his friends were of considerable importance, not merely in exploiting traits of his character, but in throwing light on his literary taste, his outstanding clarity of expression, his exceptional intelligence and his varied sympathies. ${ }^{(4)}$

During his early period of writing poetry, which dates from the mid fifties until 1862, Thomson's poetry was packed with the sweetest idealistic visions, vibrant natural colours and the tenderest dreams of love. Although there were occasions, during that period, when the gloomy side of his character would find expression in poems like "The Doom of a City" (1857), yet, it was generally a period when Thomson was able to show the optimistic mood and happy side of his nature. He even found life and nature "So rich and sweet" that he" must sing: of mountains, deserts, seas " ("For I Must Sing of All I Feel and Know" (1.7)

Some of Thomson's early poetry even witness for his absolute belief in human amelioration, the immortality of the soul, and the total benevolence and wisdom of God. In "The Lord of the Castle of Indolence", he affirms that While some skeptics "fumed and schemed and toiled in vain/ To mould the world according to their mood ", he believed the world's "Maker surely wiser far than we/...; All-good is He". (1 V)

Thomson published nearly a dozen of these early poems in Tait's Edinburgh Magazine between 1858 and 1860 under the pseudo name of "Crepuscules"(5) ${ }^{(L a t e r}$ he wrote under the signature "B.V." (Bysshe and Vanolis); in honour of his two icons; Shelley and the late $18^{\text {th }}$ century German writer Novalis. ${ }^{(6)}$

In 1860, Thomson began to publish verse and prose work in the National Reformer ${ }^{(7)}$. Evidently that was possible because of Bradlaugh's aid; the president and co-founder of the atheistic National Secular Society. In fact Bradlaugh's help was a sword of two edges; although it contributed to Thomson's publicity, but at the same time it gave rise to outrageous accusations of Thomson as an atheist, and the prosecution of his philosophical poem, The City of Dreadful Night, as blasphemous.

In 1862, Thomson was discharged from the army as a result of the trivial incident of bathing in a prohibited pond! ${ }^{(8)}$. With the help and generosity of Bradlaugh, Thomson got a job and shelter in London.

The change in Thomson's mood coincided with the change of his career and London's stern life style. "His beliefs were altered; he no more believed in the immortality of any particular soul" ${ }^{(9)}$ and that was accompanied by an adjustment of most of his early convictions. It looks like an initiation ritual that most thinkers have to go through to arrive at the final stage of their development and subtle philosophical views .However, and as Salt confirms, freethinking for Thomson was not the synonymous of atheism; neither in practice nor ideology: "while Thomson thoroughly identified himself with the party of Free-thought, he never degenerated into the mere Partisan. ${ }^{(10)}$

Publishing in the secularist National Reformer thus, gave Thomson the freedom to write what his liberal thoughts inspired him, without being forced to abide to any conventional opinion. This modification in his life and mood was interpreted as corresponding to the new characteristics of his second poetic period (1860-1874); that manifested themselves plainly in the reduction of ornament and elaboration, adjustment of thoughts, boldness of expression, pessimism and the speculative mood that culminated in writing The City of Dreadful Night.

\section{The City of Dreadful Night}

During his later period, Thomson finished writing the first two verses of The City of Dreadful Night in 1870, but left it unfinished until 1873 when he wrote its last version. The poem was published in 1874 in the National Reformer in four installments and a prefatory "proem" by the unknown "B.V." and was immediately recognized as a work of a great philosophical mind deeply stimulated by the dilemma of existence. In 1880, nineteen months before his death, Thomson published the poem once more in his volume The City of Dreadful Night and Other Poems.

\subsection{A Physical City or a City of the Mind?}

During the $20^{\text {th }}$ century, the city has mostly been presented in literature as a wasteland and a skunks' dwelling. Life in modern cities was portrayed as monotonous, inescapably filthy, diseased, and a central force of social 
corruption. However, this image was not a modern invention; but a reaction that emerged in many $18^{\text {th }}$ and $19^{\text {th }}$ century writings, when London was depicted as a city where the poor and the working class were plagued with a diversity of widespread common diseases ${ }^{(11)}$. Shelley has described London once saying, "Hell is a city much like London" ${ }^{(12)}$, and the same image of awful London was utilized and documented by many writers and poets. The 'city' for many of these writers became a place scornful of man's dreams and thoughts; that leads its inhabitants ultimately to drift from each other. It became very perceptible, from the industrial revolution on, that whenever the 'city' is mentioned in literature, it brings to mind the associative elements of exploitation, alienation, corruption, sickness, poverty, cruelty, loss of faith, frustration, discontent, temptation and all sorts of repulsive thoughts.

In his poem entitled "William Blake", Thomson's description of Blake's London reflects the dissatisfaction with the city and the feelings of estrangement that Blake has embraced before him; " the desert of London town/ Gray miles long" where thousands live "But some were deaf and some were blind", and the poet "was there alone" in that "desert of brick and stone". (11. 9-12)

Accordingly, many critics ${ }^{(13)}$ believe that Thomson's 'city' would certainly be London; the Victorian metropolis. They argue that Thomson's narrator in The City of Dreadful Night took his journey through one night of the deprived side of the 'doleful city' of London where poverty, hunger, crime, and 'unutterable', 'incalculable' and 'incurable' 'infections' of all kinds reside. (XV, 11. 18-20)

The poet explains his reasons for tackling such an unpleasant subject writing:

Because a cold rage seizes one at whiles

To show the bitter old and wrinkled truth

Stripped naked of all vesture that beguiles,

False dreams, false hopes, false masks and modes of youth;

(Proem, ll.8-11)

However, if Thomson is describing his disappointment with the bad situation of the real city of London and that the poem is a mere reaction to the pervasive apathy of London, then we have a problem; because the geography of The City of Dreadful Night is out of place with its own identity. The city is depicted as existing in a detached reality; in the middle of a wild, alienated and outlandish nature; a place made up of ' trackless wilderness', 'Savannahs' and 'savage woods', 'Bleak uplands' and a 'shipless sea's unrest' (1, 11.32-35). A city that appears bizarre, deeply complicated and instable. It seems to exist neither amid the sublime romantic nature, nor amid a prosperous industrial metropolis. Nevertheless, some critics ${ }^{(14)}$ insist that The City of Dreadful Night was inspired by the urban terror and despair Thomson encountered in the city of London and that the poem foretells the dreadfulness and corruption of living in such metropolitan dehumanized society. In fact, Thomson's poem is generally referred to as 'London poem' ${ }^{\prime(15)}$ and might actually portray London's condition as a diseased city at that time. Yet, this material setting with all its silent streets, the waste marshes, dim gas lamps and the desperate souls of its worn- faces dwellers seem to portray a city that no one can unerringly identify. The urban topography is complex and might intermingle with some of Thomson's blurred memories of 'any' other city. On the other hand, the poet might be utilizing his intense imaginative gifts in portraying that paradoxical city; to seem at once "not ruinous" yet, "Great ruins of an unremembered past" coexist in it. At any rate, we should neither be tempted to draw inferences from such affinities between London and Thomson's city, nor regard this city simply as the source of Thomson's actual hardships expressed in the poem. Inadequate emphases on the mere biographical facts in interpreting this poetic experience would de-emphasize the real worth of the poem. We would better recognize the talent behind such a beautiful expression, rather than lament the poet's misfortune; for Thomson might be blending the real features of the city with the illusionary and ghostly to create a strange, symbolic and distinctive world of his own.

Other critics confirm that Thomson's city is not to be identified as any actual urban habitat, and that the poem's narrator roams in a "nightmarish urban labyrinth of muted signs and gestures."(16) They believe it to be an allegorical city made in the image of London, transformed by the eye and mentality of a desperate man whose heart was filled with weariness and his mind with desolateness, and inhabited by the narrator and his likeminded. They conclude that Thomson could be creating a city of the mind rather than an actual one.

To verify their theory, these critics provide as evidence the three opening epigraphs of the poem, selected successively from Dante's "Inferno", and Giacomo Leopardi's two works: "Canti XX111: Canto notturno di un pastore errante dell' Asia", and "Dialogo di Frederico Rusch e delle Sue mummie". The line from Dante is translated as "Through me is the way into the city of pain". While Leopardi's lines are translated as: "Then out of 
such endless working, so many movements of everything in heaven and earth, revolving incessantly, only to return to the point from which they were moved: from all this I can imagine neither purpose nor gain", "Eternal alone in the world, receiver of all created things, in you, death, our naked being comes to rest; joyful no, but safe from the age-old pain...For happiness is denied by fate to the living and denied to the dead."(17)

According to such a reading, Thomson's cursed city would correspond to a mental picture where the narrator wanders in the bewilderment of his soul's depths searching for answers. Therefore, these epigrams could be interpreted as psychological states of the human suffering, and of loneliness and eternal despair, rather than an actual urban topography that matches London, or identifies with any other particular city. Consequently, Thomson's stroller could be roaming inside his outworn soul where he imagines hearing "...strange voices join stranger talk/...These bodiless voices in my walking dream." (Vl, 11.9 \& 11)

The lines:" I stood a few steps backwards, desolate; / And watched the spirits pass me to their fate"(Vl, $11.40-41)$, and the lines where he describes the supposedly natural succession of the day and night as "...present in distempered gloom of thought/ And deadly weariness of heart all day" (1, 11.9-10) further intensify this idea. To extend the belief in the symbolic interpretation of the 'city', one may even reflect on the two despairing opening lines of the proem taken from Shakespeare's Titus Andronicus: "In the dust I writ/ My heart's deep languor and my soul's sad tears". These lines reinforce the conviction that the 'city' here is an articulation of a condition of estrangement and not an account of the city's physical horror. The poem, thus, could be read as an emblematic attempt to search for understanding in a meaningless existence.

Whether the first perspective of the factual city or the second of the fictional mental state is true, Thomson blends successfully these two contraries and integrates the material city with the metaphorical efficiently. The borderlines between illusion and reality are intentionally left vague, and the 'city' immediately emerges as a symbol of both actual and fanciful practices and perceptions. The 'city' could be an imaginative medium employed to convey an increasingly dreadful vision. Thomson's 'city' clearly forecasts the moral and economic darkness of19th century London, but his multilayered picturesque vision permits the reader to treat this artistically inspired notion just as real as real things . It is the poet's ingenious power of imagination that allows a dreamlike object to function as a real thing in the world of reality. It is a testimony that reflections are no less valid than reality.

\subsection{The Poem's Narrator and Other Characters}

To decide whether the speaker in The City of Dreadful Night is Thomson himself, or a variety of narrators who represent the contrasted aspects of Thomson's poetic utterances, or even an independent persona; is another controversial matter. The writer is no doubt a 'seer' who translates his vision of the city into a vibrant picture of a disintegrated place engulfed in perpetual darkness. Thomson seems to be the speaker of the following lines from the proem:

Surely I write not for the hopeful young,

Or those who deem their happiness of worth,

Or pious spirits with a God above them

To sanctify and glorify and love them,

Or sages who foresee a heaven on earth.

(Proem, ll.15-21)

Upon declaring his purpose of writing the poem, Thomson makes it explicit that he is targeting and trying to reach out to the society of the deprived:

Whose faith and hopes are dead, and who would die.

Yes, here and there some weary wanderer

In that same city of tremendous night,

Will understand the speech and feel a stir

(Proem ll.28-31)

There is no clue whether Thomson will continue leading us through this journey, or hands us over to another narrator. However, the narrator-who may or may not be the poet-seems himself to be a ' weary wanderer' who is taking a journey inside the hellish city in search of some meaning to life. How the narrator gets into the city 
mysteriously, decidedly alone and unguided, "none can clearly know."(V, 1.1.) Yet, what appears remarkable here is that the wanderer is not alone in his suffering or search; but a group of fellow victims joins him:

\section{"I suffer mute and lonely, yet another}

Uplifts his voice to let me know a brother

Travels the same wild paths though out of sight."

(Proem ll.33-35)

The solace of these sufferers springs from the recognition that there is fellowship in all-disastrous fight, and a whole community is sharing the same destiny. Such unity of isolated and desperate individuals, multiplies the intensity of the poem. Since the narrator is entrapped with the others in the city and is accustomed to its malignancy, he will be our guide and an incredible observer of the details and duality of this journey. His tantalized fraternity drifts towards the land of deprivation "Myriads of habitants are ever sleeping, / Or dead, or fled from nameless pestilence!" $(1,11.48-51)$ All characters that appear to the narrator in this city are unidentified nameless figures who act as props to magnify the solitude of his journey. The narrator stalks the first phantom he encounters, for many "dim silent streets", without speaking to him; just "Because he seemed to walk with an intent." (11, 1.1) The "shadowlike and frail" man then breaks the most devastating news; murmuring: " Here Faith died, poisoned by this charnel air", "Here Love died, stabbed by its own worshipping pair", and "Here Hope died, starved out in its utmost lair" (11, 11.12, 18 \& 24). Life, thus, emerges as dead because of the corruption either of the Victorian life-style, or the tortured mentality.

Hopeless, shocked and his "soul is too outworn for wondering" $(111,1.28)$, the narrator stands alone in a world where all familiar reassurances and logic have vanished. His disjointed hopeless movements carry him to a desert; which proves to be black, with no moon, stars or sun. The narrator circles wearily; hallucinating and repeating with variations: "As I came through the desert..." (IV), stressing the monotonousness and sterility he encounters in that bleak desert. Such a circular journey might, metaphorically, signify man's vain eternal journey in life.

Although the speaker says the city is a symbol of infertility inhabited by "Mature men chiefly, few in age or youth/ A woman rarely, now and then a child" (1, 1.57-58), yet, strange enough, "A woman with a red lamp in her hand" $(\mathrm{IV}, 1.65)$ appears unexpectedly to the speaker; like a fountain in that desert of life. She rejuvenates the wanderer's enthusiasm and splits him into:

Two selves distinct that cannot join again;

One stood apart and knew but could not stir,

And watched the other stark in swoon and her;

$(1 \mathrm{~V}, \mathrm{ll} .72-74)$

Does Thomson intend this to be a call for the natural process of reproduction that will bring to this sick world another "little one from birth defiled/ Or lame or blind"! (1, 11.60-61) Or does he declare another symbolic situation? Since we are dealing with an enlightened poet, then planning to involve another innocent creature in the wretchedness of this diseased city seems bizarre. This leaves us with the symbolic interpretation that sounds more logical. It looks as if the poet is splitting his character into the real everyday man living among us and the sensitive literary figure who is searching for a role for poetry in commenting on what is happening in life around him. If so, the poem thus, could be read as an attempt to dramatize the quest of the artist and explore the conditions, commitments, agonies and inner conflicts of his creative self, and their effect on the human soul. It could be a study in the conception and demands of art versus the claims of humanity. His thinking poetic self is watching his worldly self extinguish under life's pressures. After all, this deeply divided soul and 'fractured identity' of things pervades the whole poem, and personifies the split throughout it. This double self of the speaker; as an artist and a regular person manifests Thomson's poetic and personal philosophy. In one of his essays, Thomson presents Shakespeare "as the supreme and typical example of the wise man who will practise art only so long as he is compelled to do so by circumstances, and will return to actual life from the mere study of life on the earliest opportunity." ${ }^{(18)}$ If so, one might consider Thomson as calling for 'dissociation' of the personal life of the writer from his literary work, even before T.S.Eliot did so.

Thomson uses this imaginary medium of the 'split soul' to convey an increasingly tragic vision. He could be thinking of alienation and suffering imposed by 'art' as a price to maintain a higher artistic life. However, he is not suggesting simply the aligning of a community of just likeminded intellectuals who care for poetry and are trying to establish a union for self-indulgent elitism. Thomson could be reaching to a particular community of 
isolated sufferers who share their calamities silently and could understand each other. He is positing the vital social role of poetry that presents the possibility of sharing the poet's same sentiments and concerns by a fellowship of equally intelligent readers. He affirms, "In plain language; poetry organizes the world in order to extract meaning out of it." ${ }^{(19)}$ Accordingly, The City of Dreadful Night might contain the most significant philosophy of seeking to furnish the reader with a dissection of his life, to allow him understand the confusions that encircle his existence. The poem could provide, as well, the valuable means for comfort by knowing that one is not actually alone in this quest. Such recognition of unification in loneliness is what humanity needs to share. Therefore, the poem could be read as advocating frankly the missing elements we all human beings need: understanding and acceptance without judging. The poem, hence, could act as a unifier of all perspectives.

When the woman approaches his fainting ripped half, his watching conscious self notices that "A large black sign was on her breast " $(1 \mathrm{~V}, 1.82)$, which he realizes to be her own bleeding heart. Holding her burning heart as a gesture of dedication to show compassion, the woman bends above the narrator's senseless corpse, trying desperately to revive him; murmuring the precious words "of pity, love, and woe"(1V, 1.93), in vain. Then suddenly the desert tide sweeps:

.....up to her there kneeling by my side,

She clasped that corpse-like me, and they were borne

Away, and this vile me was left forlorn;

They love; their doom is drear,

Yet they nor hope nor fear.

(1V, ll.99-105)

Is this the narrator's hallucinatory account of a desert with its imaginary tides, or Thomson was introducing the world of a surplus male deserted to metropolitan industrial obscurity! And how does the figure of the devoted woman fit in such a sterile environment! Is it possible that Thomson was commenting on the Victorian crisis of banishing the female in the name of progress! Is he dealing with a bleak universe of male chronic obsessive behaviour; of men who are preoccupied with sex and material retribution! No interpretation could be ruled out.

Leaving the desert, the narrator sits lonely on the riverside, when he suddenly hears strange phantoms' voices "Flowed dark words blending with somber stream", exclaiming " And you have after all come back; come back." (V1, 11. 9 \& 13) His return was a testimony to his failure; which reminded him of the disappointment he confronted at the gates of hell when a demon warden asked him to:

"Leave hope behind, all ye who enter here."

And would have passed in, gratified to gain

That positive eternity of pain

Instead of this insufferable inane.

(V1, ll.21-24)

People in this city do not search for hope to live by; but to pay for their entrance to hell! Nevertheless, the narrator did not mind doing so, but the problem was that he had lost all hope years ago and has none left to cast at the doors of inferno now. Because he could not gain the relief of eternal hell "Without the payment of the settled toll", he began searching for a minute of lost hope to trade it for "That positive eternity of pain."

Next, he overhears two citizens, meeting by the river of suicide, complaining how life has denied them even their modest needs of "homely love with common food and health" (V111, 1.16). The justification comes straight away; that life is simply indifferent to man; because it has no purpose, heart, mind or will.

The narrator finds it suitable now to introduce himself and his fraternity. Just like the other inhabitants, he and his group are gloomy, disgusted of their present life, terrified of its closing stages, have given up hope and faith, and although "They have much wisdom yet they are not wise" (X1, 1.8). They have strong will, yet, predestined, "They are most rational yet insane" (X1, 1.15). Some of them appear either deformed, have unidentified shapes or strange figures or have some sort of abnormality; as if the city was under some sort of curse. In addition, they share the most distinctive feature of assembling a brotherhood of equals:

And some are great in rank and wealth and power,

And some renowned for genius and for worth; 
And some are poor and mean; who brood and cower :yet these and those are brothers,

The saddest and the weariest men on earth.

$(X 1, l l .22-28)$

Thomson here is deconstructing the typical diseased Victorian society with its class structure, and reconstructing it to be consistent with his own ideal version. In his visualized city, there appear no class divisions, and his choice of comrades is not based on any social criteria. Regardless of relative wealth or poverty, all members of his consolidation are equally subjected to the misery of the original curse of their existence, and strange enough, they all embrace silently this meaninglessness. Therefore, the unity of the poem could spring from its characters' apprehension and acceptance of the bleakness of their persistent imprisonment in that city.

Although The City of Dreadful Night seems "so alien from common thought and feeling", as Thomson admits in a letter to Dobell in $1874^{(20)}$, nevertheless, there is an earnest message in it. "What he was trying to express was not the harmony of life, but the meaningless discords of it" (21). Apparently, Thomson was not moralizing, but sharing with his readers his account of some common existential problems. In one of his essays, Thomson wrote, "Though no word of mine will ever convert anyone from being himself into being another me, my word may bring cheer and comfort and self-knowledge to others who are more or less like myself, and who may have thought themselves peculiar and outcast."

Despite the poem's negative vision, it still could be read as an articulation of an exceptional imaginative mind, and a search for the role of poetry in shaping communities. Thomson might be suggesting that poetry could afford those who feel lonely in life, the valuable gift of bonding by means of understanding.

\subsection{A City of God or an Atheistic City?}

Publishing The City of Dreadful Night in Baudlaugh's National Reformer was cause enough to condemn Thomson's poem and label it as 'blasphemous'. Although introducing the crucial issue of turning to religion for explanation or meaning in a chaotic world was not astonishing, however, the 'cathedral scene' in The City of Dreadful Night provoked some readers to judge the poem as atheistic.

Unexpectedly, our narrator comes across a young man murmuring Prayers of eternal grief. The young prayer was kneeling beside the Lady of images begging desperately for a liberating, relieving and merciful death; since he feels he is turning into cold stone while still alive. Did he lose compassion, or belief, or both! No explanation is given.

The scene now shifts to a congregation assembling within a cathedral inside the 'city'. Our narrator wanders dejectedly into, to attend the sermon, where he hears the preacher announcing loud and clear " There is no God; no Fiend with names of divine", and adds that "This little life is all we must endure"! (X1V, 11.40 \& 49)

Shockingly, the man who is expected to have faith and preach patience and love reverses all props of religious life and traditional forms of worship, and finds comfort in despair and nihilism! Moreover, he poisons his worshippers' souls by denying them even their instinctive traits, declaring "I find no hint throughout the universe/Of good or ill, of blessing or of curse." (X1V, 11.73-74)

Since he rules out the presence of divine mercy, punishment, and afterlife, the preacher appears to be constructing his own materialistic city as a reversal of the city of 'light'. He terminates all meaning ascribed to religion; by allowing all prohibited sins when he proclaims "But if you would not this poor life fulfill/ Lo, you are free to end it when you will." (X1V, 11.82-84)

The worshippers could not expect a more dreadful climax for the sermon than that of sanctioning suicide as a solution to end their misery! Instead of teaching his flock the true Christian dogma that regards ending a human life as one of the fatal sins, he propagates it. The poem does not suggest a way to God's absolution, neither presents its citizens with the option of a satisfactory life, nor even leads them to any sort of purgation. The ultimate collapse of religion in a scientific world is implied, and Christianity in this 'city' is announced as a disarmed entity that has neither authority nor solutions. Most $19^{\text {th }}$ century writers were convinced that redemption through religious, or secular solutions, or even a repeated cycle of another historical golden age became all farfetched. George MacBeth confirms "The Death of God is a key theme in later nineteenth-century poetry, and Arnold was one of its pioneers." ${ }^{(23)}$ Although this explains the familiarity of the Victorian mind with this crisis of disbelief, yet, it does not explain why these Victorians could forgive what they considered Arnold's "stoical rejection of them (old faiths) as outworn things" (24), but cursed Thomson's The City of Dreadful Night and considered its writer an atheist! Dobell confirms that what Thomson "most keenly detested and satirised in 
so-called religious life was the self-seeking, self-conscious spirit, which, under the guise of piety, is intent on the saving of its own soul and the securing of its own immortality." ${ }^{25)}$ Meeker, as well, affirms that:

"It is not for most of us, who smile at Mid-Victorian theology, to criticise Thomson for nobler, wiser and more acute criticisms of it than our own. Actually, Thomson was never an unreligious man, nor could he for long escape spiritual problems. "(26)

Despite the preacher's distressing lesson in the chapel, we may venture to say that the 'city' itself does not seem totally Godless. ${ }^{(27)}$ One of the men sitting by the river of suicide says, "The vilest thing must be less vile than Thou/ From whom it had its being, God and Lord!"(V111, 11.24-25) Although God is blamed here, yet, He is at least not forgotten or dead.

The narrator does not comment on the preacher's atheism, and Thomson assigns this responsibility to two listeners; one celebrates this approach as "good tidings", and the other dismisses it as truth. Thomson, intentionally, adopts the technique of ambiguity as concerning the speaker, in order to have the freedom of expression. Therefore, it becomes difficult in all instances to ascribe either point of view exclusively to Thomson.

It is hard to affirm without doubt whether this emphasis on the futility of faith and the distortion of the religious code of beliefs, is intended to be a mere verbal expression of dissatisfaction with the Victorian scene; or meant to be interpreted as another mental image. After all, any loss of faith in any ideal could be identified equally with a moral or mental wasteland. Yet, Thomson's 'city' is certainly not Dante's holy inferno of sinners who are denied even human utterance. On the contrary, Thomson's city inhabitants have the relief of community that stems from the recognition of isolation. This acts as a substitute to the unity and meaningfulness those traditional codes of belief used to bring into man's world before; and are aborted now.

\subsection{Philosophical or Personal Pessimism?}

The sense of futility is no alien to Thomson's poetry. The prevailing theme in a good deal of his writings was that of estrangement; in all its physical, spiritual and mental aspects. In a poem entitled "Insomnia" (1882) Thomson deals with the theme of "dreadful silence and deep gloom", and in "In the Room" (1868) the vision of aching inevitable isolation takes over that the room's furniture discusses the bleak situation leading to the body of the suicide on the bed; denying the poem thus, even human utterance. To his most characteristic poem The City of Dreadful Night, Thomson adds the theme of the quest where characters roam the city aimlessly longing for understanding, acceptance, and the solace of union in solitude within an alien urban environment. Yet, the theme that inclusively takes hold of the reader of The City of Dreadful Night is the pessimistic vision brought about by the frustrating result of the search. The 'city' in this poem is "of Night; perchance of Death" $(1,1.1)$, its inhabitants are denied the anticipation of any ideal, and the quest ends in a world worse than hell. The poem neither presents its inhabitants with a bearable life, nor with a positive eternity; but merely suggests an endurance of miserable life until the certitude of death brings the desired oblivion. Such a dark vision would indisputably mark Thomson as the 'laureate of pessimism'. ${ }^{(28)}$

Thomson's attitude towards pessimism is summarized in his introductory remarks prefixed to his poem "A Lady of Sorrow". He speaks of despair as having:

Manured some of the fairest flowers of Art and Literature...The night-side of nature...has been the theme of literature more often than the day-side, simply because literature, as a rule, is the refuge of the miserable. ${ }^{(29)}$

Actually; pessimism, mental confusion and darkness that haunted many $19^{\text {th }}$ poets were embedded initially within some philosophical debates; especially those of the German thinker Schopenhauer (1788-1860) who raised questions as concerning the individual will and the purpose of life. As for Thomson's The City of Dreadful Night, Salt observes that:

The sense of 'sanctitude and piety', finding action in services of gentleness and tenderness to suffering fellow-beings, is a most important and characteristic feature of Thomson's pessimism, relieving it altogether from any suspicion of misanthropic churlishness, and allying it not only with the most valuable part of Schopenhauer's philosophy, in which compassion is made the principle of moral action, but also with the tender and benevolent sadness of Buddha. ${ }^{(30)}$

Hence the sympathetic endeavor of launching a brotherhood for the miserable on earth in The City of Dreadful Night.

Another shaping influence of Thomson's pessimism could be Giocomo Leopardi (1798-1837), to whose memory Thomson dedicated his poem. Thomson apparently was inspired by Leopardi's pessimistic sense of 
disappointment and frustration with life, his belief in the wretchedness and futility of existence, and the sense of loneliness and estrangement inflicted by the diseased city living. This impact is ascertained by the fact that Thomson not only dedicated The City of Dreadful Night to Leopardi, but also prefaced it by quotations from Leopardi; that inspired the concepts and the mood of the poem.

The other noticeable impact was that of Henrich Heine (1797-1856); whose pessimistic poetry Thomson has translated in a skilful manner that appealed even to Dr. Karl Marx who "expressed his delight at the versions from Heine, which he described as "no translation, but a reproduction of the original, such as Heine himself, if master of the English language, would have given." ${ }^{(31)}$ Thomson felt a bond and kinship to Heine as another sufferer, and portrayed him as:

"In all moods tender, imaginative, fantastic, humorous, ironical, cynical, and in anguish and horror, in weariness and revulsion, longing backward to enjoyment, and longing forward to painless rest; through the doleful days, and the dreadful immeasurable sleepless nights." ${ }^{(32)}$

Words that are principally true of Thomson himself too. The resemblance between Thomson's line of thinking and these writers' is incredible.

Another influence could be that of Albrecht Durer (1471-1528). In a letter to W. M. Rossetti, Thomson admits having "Long been profoundly impressed by the "Melancholy" of Durer...Wishing to bring this great figure (Melancholia) into a poem, and rapidly enumerating the accessories which help to identify it" ${ }^{33)}$ Thomson's wish came true when he introduced Durer's engraving of 'Melancholia' in the last stanza of The City of Dreadful Night as the queen and patron saint of the 'city', who resides over that wasteland and signifies the spirit of the age. Did Thomson intend her to be an" emblem of the human race which struggles with a vain but continual heroism against its birth destiny"(34) as Meeker suggests! Or to symbolize man's mind disease! Any and both interpretations are possible:

An image sits, stupendous, superhuman,

The bronze colossus of a winged woman,

Upon a graded granite base foursquare.

$(X X l, l l .5-7)$

This is the second female figure that appears in the 'city'. Since 'Melancholia' is engraved with a book in her lap and surrounded by scientific tools, she seems symbolically associated with scientific and industrial expansion. However, this sphinx- like creature is impotent and unable to carry the burden these technological adaptations cause, although she tries patiently:

Baffled and beaten back she works on still,

Weary and sick of soul she works the more,

\section{Till Death the friend-foe piercing with his saber}

That mighty heart of hearts ends bitter war.

$(X X l, l l .50-56)$

If even such a powerful creature feels the futility of her labour, then what purpose and end would following her way of dealing with the problem serve! She, too, surrenders to the city despair and confirms science's inefficiency to offer any solution to man's dilemma.

Thomson found it useless and irrational to confide in any "schemes for the improvement of the human race."(35) He realized the breakdown of all available systems, the futility of any effort, and the impossibility of progress in the face of the merciless and impenetrable fate. Despite his sympathetic attitude towards humanity, he seems to be devoid of any hope or confidence in human progress or perfectibility. In a prose essay entitled "Immortality!" Thomson exclaims:

"why, the most of us don't know what to do with this one little personal life, and might well wonder how we came to be promoted to the dignity thereof; the claim to immortality is the claim to be trusted with millions of pounds because one has shown himself unfit to be trusted with sixpence."(36)

If there was no improvement after centuries of serious labour and relatively advanced religious, political, economic and social movements, then why would we expect the appearance of a perfect human race, or better conditions now! 
Yet, Thomson's pessimistic view of humanity and its future appealed to some writers as refreshing. Commenting on the complaints raised against Thomson's dark mood in poetry, Herman Melville said: "although neither pessimist nor optimist myself, nevertheless I relish it in the verse if for nothing else than as a counterpoise to the exorbitant hopefulness, juvenile and shallow, that makes such a muster in these days." ${ }^{\text {(37) }}$

G. W. Foote perceives Thomson's pessimism as "not a mood, but a philosophy, the settled conviction of a keen spectator of the great drama of life" ${ }^{\prime(38)}$, while others find it an "expression of a dominant mood amounting to personal conviction" ${ }^{(39)}$. Numerous critics prefer to overlook Thomson's philosophical mind and ascribe his pessimistic writings totally to his life's hardships, or on occasion to his time's incurable evils. They interpret the essence of his pessimism as simply a response to personal misfortunes and read The City of Dreadful Night as extremely entrenched in his personal life. In his book, The Laureate of Pessimism, Dobell ascribes Thomson's pessimistic writings to his" acute sensibilities which verged upon, and sometimes overpassed, the borders of morbidity... It was the cause at bottom which led...Thomson to regard the world as a scene of black and immitigable despair. ${ }^{(40)}$

The Cambridge History of English and American Literature, also, states that "'Melancholy, of ... blackest midnight born', marked him for her own, and under her baleful influence, he fell a helpless victim to intemperance and disease", and goes on advising his readers to contemplate on this idea as "the first consideration to be taken into account in any judgment of Thomson's poem." ${ }^{(41)}$

Advocates of the approach of the personal drives behind the poem's bleak mood ascribe Thomson's pessimism to the premature death of his supposed beloved Matilda Weller. ${ }^{(42)}$ Others are convinced that his pessimism is inherited from his mother who was described as having "a cloud of melancholy hanging over her." ${ }^{(43)}$ Still others find it a result of his financial difficulties, addiction to alcoholism, poor health and insomnia that plagued his last years. ${ }^{(44)}$ He wrote to George Eliot that The City of Dreadful Night "was the outcome of much helpless hypochondria." ${ }^{(45)}$ Yet, being afflicted with insomnia could very likely become an incentive source of both: annoyance, as well as inspiration.

It is a proven fact that no human being is immune of despair. We all have rambled the streets of such a nightmarish 'city' of dreadful night' at a certain stage of our lives. Besides, we are aware that some people are more jeopardized to afflictions of pessimism than others; particularly intellectuals who get acquainted with the dark mood at some time of their life. However, one cannot entirely rule out the possible impact of Thomson's personal hardships in shaping some of the insightful thoughts and sensitive feelings embraced in The City of Dreadful Night. Yet, it would be a great injustice to judge such an impressive poem solely in the light of a psychoanalytic study of its writer's life; overlooking thus, his mind's philosophical analysis, somber imagery, novelty of tone, solidity of grasp, unity and coherence of the poem, and his real cultured taste and gift of depicting the rhythms of human life around him. It is natural that literature does not emerge from a vacuum and that some life's experiences linger in the human impressionable mind, yet, the extent to which these personal experiences shaped Thomson's writing, might be overrated, exaggerated, misleading, or speculative.

In fact, Thomson was not a totally pessimistic person throughout his whole life. "All his friends bear testimony to the genial and sunny side of his character." ${ }^{(46)}$ G. G. Flasws admits that he is "far from saying that Thomson did not find any happiness in life. His wit and broad fun vied with his varied information and gift of happy talk in making him a prince of good fellows." ${ }^{(47)}$ Dobell affirms he "could hardly wish for a better companion than he was"(48), and Thomson's last poems, testify to his cheerful mood, despite the heartbreaking conditions he went through prior to his tragic death. "At Belvoir" (1881), conveys such peaceful, melodic and joyous sentiments; where he chants to the "Sweet happy thoughts" that make "the saddest heart/In joy a true believer." (11. 2-6)

Among the other camp of critics who reject any biographical reading of Thomson's work, is Henry Paolucci, who proposes that "Thomson evidently expected his readers to come to his City of Dreadful Night not with vaguely informed curiosity about his personal life, but with the sound of poetry in their ears." ${ }^{(49)}$ Although each reader can settle for himself, yet, any study and appreciation of a literary work deserves to rest on its worth and its writer's talent, rather than on the desperate search for any association between the work and the writer's biography. In Thomson's The City of Dreadful Night, we should focus on the merits that George Meredith admired in this poem; noticing "Nowhere is the verse feeble, nowhere is the expression insufficient; the majesty of the line always has its full colouring." ${ }^{(50)}$ We may add to these: the profound expressions of an exceptionally inspirational poet, the genuinely sympathetic feelings that intensify and broaden his picturesque vision, and the successful venturing into a subject matter most suitable to his lyrical gift.

Whether Thomson has cultivated his poetic pessimism and sense of estrangement for personal causes, or under cultural intellectual influences of some pessimistic philosophical thinkers, the result does not change the fact that 
the poem is a witness for its writer's artistry and creative ability that transcends even its pessimism.

\section{The Poem's Legacy}

The City of Dreadful Night is a key poem in defining the absolute despair that engulfs humanity in its futile search for meaning and a way out of its existential dilemma. The choice of such a dark topic and approaching it in the most striking manner, is in itself, a departure from, and a rejection of the reformers' optimism that marked some Victorian literature. The poem attracted attention to Thomson immediately and was received as a considerable literary achievement of incredible emblematic force, and its writer gained tremendously gratifying receptions. George Eliot offered the most encouraging criticism when she wrote " I cannot rest satisfied without telling you that my mind responds with admiration to the distinct vision and grand utterance in the poem." ${ }^{(51)} \mathrm{W}$. M. Rossetti wrote to Thomson "when your poems come out, I may have an opportunity of expressing publicly the deep admiration I have for your work, which seems to me powerful, beautiful, and masterly, and full of deep and beautiful sympathy with the sad race of men. Few poems in these days have more impressed me."(52). In his, Memoir $l l$, J. A. Symonds praises Thomson adding "there is no English poet now living, except Tennyson, Browning, Swinburne, and Morris, who comes near him."

Instead of sharing the $19^{\text {th }}$ century Victorian writers their tangible realism, Thomson resorted to the grave allegory of Dante and Novalis in portraying the insecurity of the tormented human minds trying in vain to fit in a primarily metropolitan fragmented community. In tackling the motif of the alienated dysfunctional individual in a hostile urban environment, Thomson should be accredited for his valuable contribution of spotlighting and spreading the literary phenomena of the evils of living in a modern city that converts its inhabitants into faithless and hopeless estranged creatures. The recurrent motif of the death of 'faith', 'love' and 'hope' in The City of Dreadful Night may correspond symbolically to the death of the 'spiritual', 'physical' and 'mental' human faculties in life; which seems a modern approach .

Such a contaminated city became towards the end of the $19^{\text {th }}$ century synonymous with modernity and the metropolitan horror experienced, specifically in London. Amy Levy, an urban poet, praised Thomson confirming "he has symbolized, as no poet has done before him, a certain phase of modern feeling, I was going to say pessimism, but the word scarcely covers the sense" (54)

Dissatisfaction, disbelief, despair, isolation and dissociation employed in this poem, are conditions of modernity; techniques inextricably associated with the culture of modern city life; which proved vital for the poem. Thomson detached himself deliberately from the poem and its events by introducing, not only an unheroic narrator, but other pathetic figures that the narrator will stumble upon later; which sounds a highly advanced technique. Such innovative methods enabled Thomson to explore, comment and criticize freely the different points of view of city people.

If modernity of a literary work is measured by its moving away from either its usual contemporary topics, or from the traditional treatment of these topics, then Thomson in The City of Dreadful Night was venturing into modernity, and his poem was destined for posterity. Since the crisis in The City of Dreadful Night still applies to present life and is comprehensible to modern city dwellers, this poem will remain alive as long as people will experience its same conditions.

The City of Dreadful Night has inspired dynamic debates and initiated a long line of texts in modern literature, with themes and titles remarkably identical. Critics affirm, "The title of The City of Dreadful Night was reused as the title of short stories by Rudyard Kipling and O. Henry. The poem was the inspiration for the title of John Richey's novel City of Night and the first stanza of the poem was quoted in the book." ${ }^{(55)}$ The poem's heritage flows further seeping into Judith R. Walkowitz's City of Dreadful Delight (1992), which owes much to the poem's title.

When interpreting Thomson's city as a symbolic projection of the unconscious mind and an intellectual setting, the poem then, could be considered a precursor to T. S. Eliot's Wasteland (1922), and Alasdair Gray's Lanark (1981). Studying T. S. Eliot's Wasteland, Robert Crawford noticed "It was Thomson who let Eliot see Dante a poet of modern London, who let Eliot connect Dante with other modern urban writing, and who showed him that London, like Dante's infernal city, could be seen as a city of the mind as well as a city of external world."(56)

\section{Conclusion}

The City of Dreadful Night is a poem of incredible doubles, where multiple levels of meanings and implications are simultaneously presented. Nevertheless, no matter how extraordinary contrasted perspectives enclose the whole poem; no conflict exists between Thomson's imaginative and allegorical tendencies, on one hand, and his rational inclinations of thought on the other; because he kept mediating efficiently between all of these trends. 
Controversy pertaining to the exact setting of this poem seems endless while the main issue remains that of the huge number of people who are physically or mentally discomforted by human intimacy. Whether Thomson's narrator was engaged in an actual journey in the dark mysterious alleys of the real $19^{\text {th }}$ century London, or a symbolic mental tour inside the murky abyss of a tormented soul, the outcome remains the same; since both started by chance and concluded in defeat. The poem culminates in presenting a realistic sketch of some metropolitan experience in an unnamed land where reality remains confounded in illusion.

The controversial issue of who the speaker of the poem is, changes nothing in the conclusion of the poem. Part of the poem's complexity arises from keeping its speaker ambiguous, nameless and unidentified. The different voices: of the detached poet who observes, the main narrator who comments, and the other figures who present the circumstances of life inside the city, all create an amalgamation of different perspectives. At the same time, Thomson plays all but is removed from the city. Still, whether it is Thomson's inner voice talking through his characters, or his speakers' points of view; all display a mode of belonging to this city and oneness with its denizens by sympathies and companionship.

Alienation, soul-crushing desolation, agony, absurdity and disease are the basic truths in The City of Dreadful Night, where no redemption seems at hand. As such, whether it is a pessimistic poem for sheer personal motives or a deliberate adoption of a cultured philosophy, the message in both cases suggests that although there could be no resolution to this entrapment, yet, togetherness in calamity makes limbo bearable. Thomson himself considers serious art as an outcome of creative despair.

We discover, as well, that no matter how negative the subject matter in this masterpiece is, yet, faith, hope and caring are not actually dead; since there is alliance in misfortune. Although this may sound paradoxical, yet, The City of Dreadful Night is unquestionably a step removed from Matthew Arnold's "We mortal millions live alone".

The crisis of belief and 'atheism' seem expected upshots of pessimism. Losing belief in the value of life, and feeling ambushed in an ontological overwhelming situation, would consequently result in the crashing of faith even in larger principles, and in questioning the ability of all religious dogmas to bring a closer. Moreover, we have to keep in mind that Thomson was not an idealist or a reformer; but a man who neither secular nor religious zeal fulfilled him. He was a rationalist and a free thinker; whose mind was estranged from both radical and popular belief systems.

The critical value of The City of Dreadful Night remains intact; both in terms of its purpose as a medium for poetic expression, and in its creative power and poignancy. Its splendour and mystery arises from the fact that despite all the multi-Layard readings the poem licenses or suggests, people can read it the way they like, deduce the interpretation that agrees with their inclinations, find in it what they search for and will surely enjoy it.

\section{References}

Cheng, Chu-Chueh. (2005). The Importance of Being London: Looking for Signs of the Metropolis in James Thomson's City of Dreadful Night. Retrieved from http://www.literarylondon.org/london-journal/march2005/Chengh.tml

Daniels, Barbara. Hidden Lives Revealed - Poverty and Families in the Victorian Era. A Virtual Archive - Children in Care - 1881-1981 (C) The Children's Society.

Dobell, Bertram. (I 9 10). Laureate Of Pessimism: A Sketch Of The Life And Character Of James Thomson (B V) London: Published by the Author, 77 Charring Cross Road, W C.

Evans, Ifor. (1966). English Poetry in the Late Nineteenth Century. London: Methuen \& Co Ltd.

Levy, Amy. (1883). James Thomson: A Minor Poet. Cambridge Review.

Grierson, Herbert J. C., \& Smith, J. C. (1962). A Critical History of English Poetry. London: Chatto \& Windus.

MacBeth, George (Ed.) (1969). Victorian Verse: A Critical Anthology. England: Penguin Books Ltd.

Meeker, J. Edward. (1971). The Life and Poetry of James Thomson (BV). New Haven: Yale University Press.

Morely, Ian. (2007). City Chaos, Contagion, Chadwick, and Social Justice. YJBM: Yale Journal of Biology and Medicine. Retrieved from http://www.ncbi.nlm.nih.gov/pmc/articles/PMC2140185/

Paolucci, Henry. (2000). James Thomson's The City of Dreadful Night: A Study of the Cultural Resources of its Author and a Reappraisal of the Poem (Ed.). Anne Paolucci. Wilmington: Griffon House.

Salt, Henry S. (1914). The Life of James Thomson ( $B V$ ). London: Watts \& Co, Johnson's Court.

Sullivan, Dick. (2005). "Poison Mixed With Gall": James Thomson's City of Dreadful Night-A Personal View. The 
Victorian Web.

Sullivan, Dick. (2007). "A Long Defeat": A Brief Life of James Thomson (BV). The Victorian Web.

The Cambridge History of English and American Literature. (1907-21). Vol. 13: The Victorian Age-Part One IV. Retrieved from http://www.bartlleby.com/223/0413.html

Thomson, James. (1881). Essays And Phantasies (London, Ballantyne, Hanson And Co., Paul's Work And Chandos Street), James Thomson, Author of The City Of Dreadful Night, And Other Poems "vanf's storv, weddah and Om-El-Bonain, And Other Poems. London: Reeves And Turner. Retrieved from http://www.archive.org/details/essaysphantasiesOOthomrich

Toronto University Online Publication. The Life Of James Thomson, Works Of James Thomson The City Of Dreadful Night, and Other Poems 53 Vine's Story and Other Poems 55 A Voice From The Nile, and Other Poems 6s Essays And Phantasies (London: Reeves \& Turner, 196, Strand_1889) H. S. SALT Author Of "Literary Sketches," The Life of James Thomson (BV)With A Selection From His Letters And A Study Of His Writings: London :Reeves \& Turner, 196, Strand. And Bertram Dobell, Charring Cross Road 1889 Sallantyne, Hanson And Co. Edinburgh And London.

\section{Notes}

1. George MacBeth, ed., Victorian Verse: A Critical Anthology (England: Penguin Books Ltd, 1969), pp. 18-19.

2. James Thomson, Essays And Phantasies, (London, Ballantyne, Hanson And Co., Paul's Work And Chandos Street), James Thomson, Author of The City Of Dreadful Night, And Other Poems "vanf's storv, weddah and Om-El-Bonain, And Other Poems (London: Reeves And Turner), Section 4" Opinion of the Press".

$\mathrm{http} / / \mathrm{www}$.archive.org/details/essaysphantasiesOOthomrich

Digitized by the Internet Archive in 2008 with funding from Microsoft Corporation.

3. J. Edward Meeker, The Life and Poetry of James Thomson (BV) (New Haven: Yale University Press, 1971), p. 75.

4. Henry S. Salt, The Life of James Thomson (BV) (London: Watts \& Co, Johnson's Court), 1914.

5. Meeker, p. 1.

6. Ifor Evans, English Poetry in the Late Nineteenth Century (London: Methuen \& Co Ltd, 1966), p. 227.

7. Salt, p. 34.

8. Bertram Dobell, Laureate Of Pessimism: A Sketch Of The Life And Character Of James Thomson (B V), (London: Published by The Author, 77 Charring Cross Road, W C, I 9 10), p. 18.

9. Salt, pp. 145-146.

10. University of Toronto online Publication, The Life Of James Thomson, Works Of James Thomson The City Of Dreadful Night, and Other Poems 53 Vine's Story and Other Poems 55 A Voice From The Nile, and Other Poems 6 s Essays And Phantasies (London :Reeves \& Turner, 196, Strand _ 1889) H. S. SALT Author Of "Literary Sketches," The Life of James Thomson (BV)With A Selection From His Letters And A Study Of His Writings: (London :Reeves \& Turner, 196, Strand. And Bertram Dobell, Charring Cross Road 1889 (Sallantyne, Hanson And Co. Edinburgh And London), p. 300.

11. Ian Morely, "City Chaos, Contagion, Chadwick, and Social Justice" (YJBM: Yale Journal of Biology and Medicine, 2007), pp. 61-72 and: Barbara Daniels, "Hidden Lives Revealed - Poverty and Families in the Victorian Era" A Virtual Archive - Children in Care - 1881-1981 (C) The Children's Society.

12. Herbert J. C. Grierson \&J.C. Smith, A Critical History of English Poetry (London: Chatto \& Windus, 1962), p. 456.

13. Chu-Chueh Cheng, "The Importance of Being London: Looking for Signs of the Metropolis in James Thomson's City of Dreadful Night", p. 2. http://www.literarylondon.org/london-journal/march2005/Cheng.html.

14. Dick Sullivan, "Poison Mixed With Gall": James Thomson's City of Dreadful Night-A Personal View (The Victorian Web, 2005).

15. Chu-Chueh Cheng, "The Importance of Being London", p. 2.

16. Ibid, p. 16.

17. Ibid, p. 5. 
18. University of Toronto online publication, p. 306.

19. Meeker, p. 141.

20. Salt, p. 85.

21. Meeker, p. 141.

22. Salt, p. 149.

23. George MacBeth, p. 28.

24. Moody and Lovett, A History of English Literature (New York: Charles Scribner's Sons, 1964), p. 320.

25. University of Toronto online publication, p. 300.

26. Meeker, p. 140.

27. Dick Sullivan, "Poison Mixed With Gall".

28. Dobell, Laureate Of Pessimism.

29. University of Toronto online publication, p. 306.

30. Salt, p. 152.

31. Ibid, p. 161.

32. Ibid, pp. 152-3.

33. Ibid, p. 77.

34. Meeker, p. 94.

35. Salt, p. 146.

36. University of Toronto online publication, p. 300.

37. Salt, p. 151.

38. Ibid, pp. 107-108.

39. Ibid, p. 150.

40. Dobell, The Laureate of Pessimism, pp. 15-16.

41. The Cambridge History of English and American Literature, Vol XIII: The Victorian Age, Part One, IV (1907-21) http://www.bartlleby.com/223/0413html.

42. Meeker p. 110.

43. University of Toronto online publication, Dobell, Memoir chapter 1, Youth, p. 4.

44. Dick Sullivan, "A Long Defeat": A Brief Life of James Thomson (BV) (The Victorian Web, 2007).

45. Salt, p. 81.

46. The Cambridge History of English and American Literature.

47. Salt, p. 135.

48. The Cambridge History of English and American Literature.

49. Henry Paolucci, James Thomson's The City of Dreadful Night: A Study of the Cultural Resources of its Author and a Reappraisal of the Poem, ed., Anne Paolucci (Wilmington: Griffon House, 2000), p. 13.

50. Salt, pp. 114-115.

51. Ibid, p. 81 .

52. Ibid.

53. Ibid, p. 157.

54. Amy Levy, "James Thomson: A Minor Poet" (published in the Cambridge Review in 1883), p. 508.

55. Cheng, p. 1.

56. Ibid, p. 11. 